\title{
The effectiveness of heat pumps as part of CCGT-190/220 Tyumen CHP-1
}

\author{
Polina Tretyakova ${ }^{1, *}$ \\ ${ }^{1}$ Tyumen industrial University, Volodarskogo Str., 38, Tyumen, 625000, Russia
}

\begin{abstract}
The article considers the possibility of increasing the energy efficiency of CCGT-190/220 Tyumen CHP-1 due to the utilization of lowgrade heat given off in the condenser unit of the steam turbine. To assess the effectiveness of the proposed system, the indexes of thermal efficiency are given. As a result of a research the following conclusions are received: The heat-transfer agent heat pump, when heated uses low-grade heat TPP and increases heat output, but consumes the electricity. Using a heat pump is effective for a small temperature difference between the condenser and the evaporator. Good example is heating water before chemical treatment. This method is more efficient than using a replacement boiler and it is used in steam selection.
\end{abstract}

\section{Introduction}

Thermal power plants (TPP) are the main source of heat and electricity in Russia. The natural gas is the main fuel for thermal power plants. The consumption of natural gas will change significantly [1] by 2030 and the share of thermal power plants in Russia will be approximately $67 \%$ of the overall total of fossil fuel thermal power plants [2]. Therefore, intensive use of non-renewable sources of energy will determine the need to improve the efficiency of their use. There are many ways to achieve this goal, one of them is to use heat pumps at the power station.

Studies have shown that heat losses of TPP capacitors reach approximately 40 percent in some cases. The one of the possibilities to reduce heat loss is to use combined cycle power plant (CCGT). The data reported calculated potential of 190/220 for improving efficiency of CCGT with the use of heat pumps.

[3]:

The composition of this combined cycle plant with low-pressure steam generator include

- boiler unit type E-500-13,8-560GN (model TRE-435/ CCGT) of JSC TKZ "Krasnyjkotel'shchik";

- steam cogeneration turbine type T-130/160-12.8 JSC "LMZ";

- gas turbine type V64.3A «Siemens AG» company production;

- turbogenerators T3FP 160-2U3-and-T3FG 63-2U3 production of "Electrosila";

- booster compressor installation3Hz-2-38/9.5-28-K.VI production of "Kazanenergomash".

*Corresponding author: polina tret@mail.ru 
There is alsouse of chimney which allows separate operations of gas turbine power plant (GTPP) and a steam turbine power plant (STPP) in the arrangement of CCGT-190/220 (Figure 1) [4].

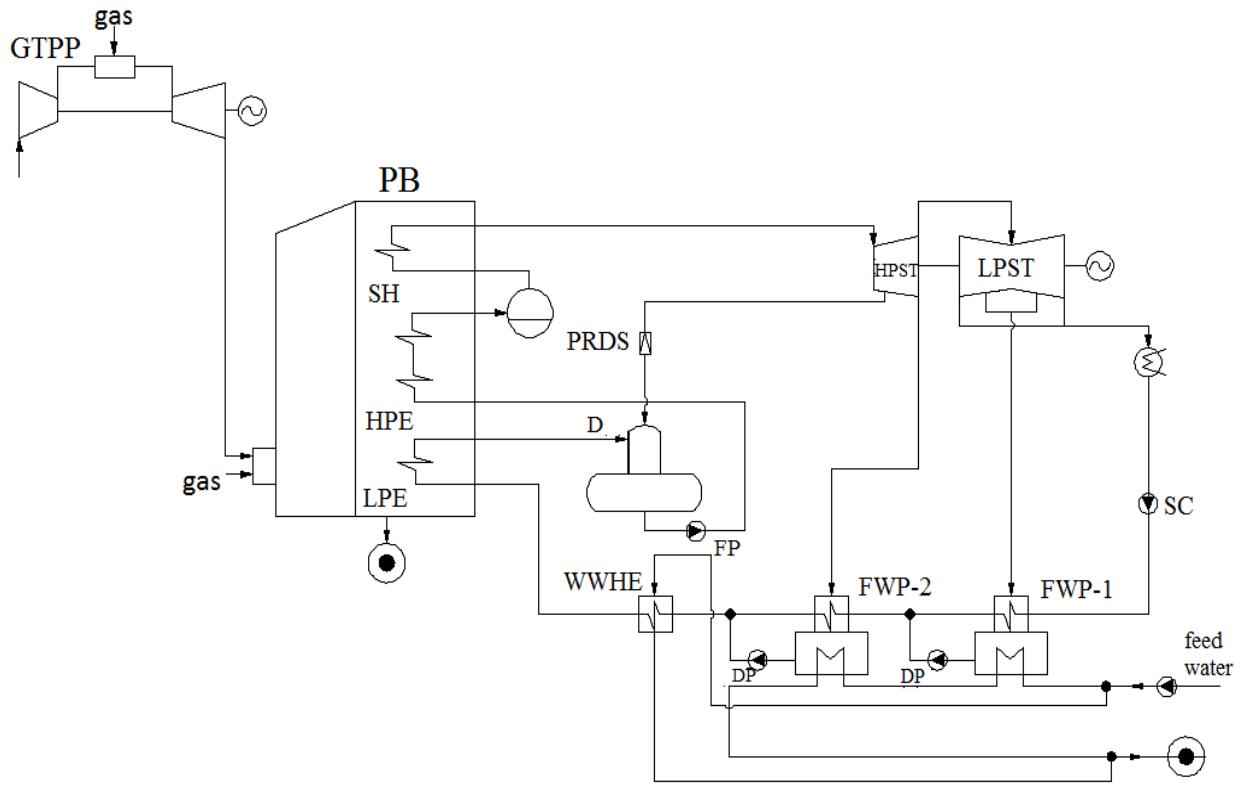

Fig. 1. Schematic diagram of the unit CCGT-190/220 Tyumen CHP-1: GTPP - gas turbine plant, PB the peak boiler, $\mathrm{SH}$ - super heater, HPE - a high pressure evaporator section, LPE-a low pressure evaporator section, PRDS - pressure-reducing desuper heating station, D -deaerator, FP - feed pump, WWHE - water to water heat exchanger, HPST- an high pressure section of steam turbomachine, LPST - a low pressure section of steam turbomachine, SC - condensate pump, DP - drainage pump, FWP-feed water heater.

\section{Materials and Methods}

The following method of calculation of thermal balance (Figure 2) was applied to the study [5].

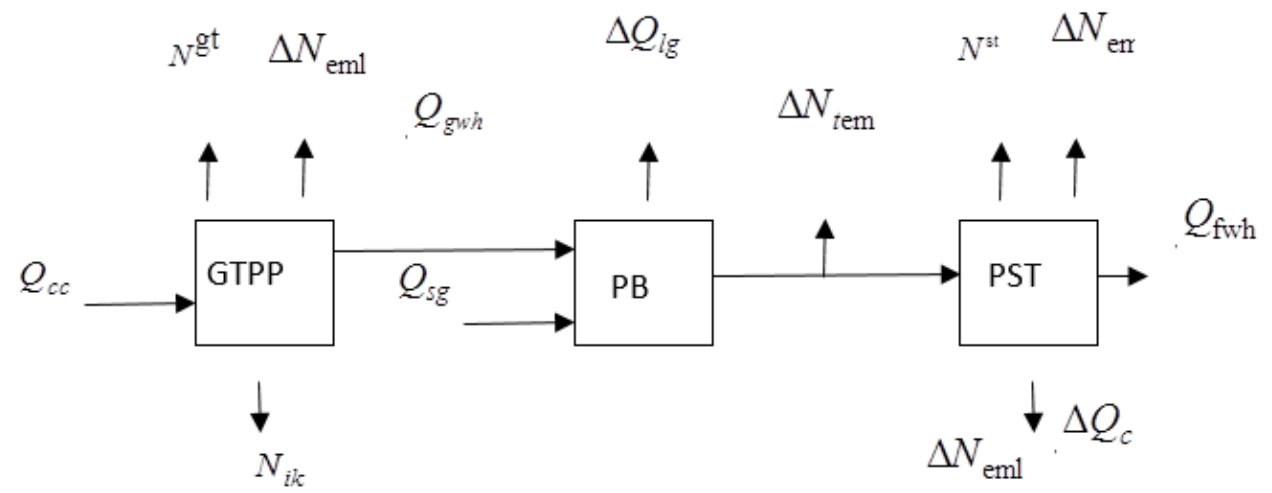

Fig.2.The heat balance of combined-cycle plant

The heat of the fuel supplied to the working fluid in the cycle CCGT, MW: 


$$
Q_{S}=Q_{p c}+Q_{g t}+\Delta Q_{\mathrm{lg}}
$$

Where: $Q_{p c}$ - consumption of heat in the CCGT, perceived in the steam cycle of the products of combustion, MW:

$$
Q_{p c}=Q_{s g}+Q_{g w h}
$$

Where: $Q_{s g}$ - heat consumption in the steam generator, MW

$Q_{g w h}{ }$ heat consumption in the gas-water heater, MW

$Q_{g t}$ - heat flow consumed for power generation in GTPP, MW

$$
Q_{g t}=N_{i g t}
$$

$N_{i g t}$ - internal power of the gas turbine, MW

$\Delta Q_{\mathrm{lg}}$ - the loss of heat from the flue gases leaving low pressure evaporator section

$$
\Delta Q_{l g}=G_{m} \quad q_{l g}=\frac{G_{m}\left(\begin{array}{ll}
h_{l g} & h_{a}
\end{array}\right)}{1000}
$$

Where: $h_{\mathrm{lg}}$-enthalpy of the flue gases leaving low pressure evaporator section, $\mathrm{kj} / \mathrm{kg}{ }^{\circ} \mathrm{C}$; $h_{a}$ - enthalpy of the outside air, $\mathrm{kj} / \mathrm{kg}{ }^{\circ} \mathrm{C}$.

$G_{m}$-mass flow of flue gas output from the low pressure evaporator section, $\mathrm{kg}$ The heat supplied to the working fluid in the cycle of CCGT:

$$
Q_{c}=N_{\mathrm{e}}^{\mathrm{gt}}+N_{e}^{\mathrm{st}}+Q_{\mathrm{fwh}}+Q_{\mathrm{sc}}+\Delta N_{\mathrm{eml}}+\Delta Q_{\mathrm{lg}}+\Delta Q_{k}+N_{i k}
$$

Where:

$N_{\mathrm{e}}^{\mathrm{gt}}, N_{e}^{\mathrm{st}}$ - power at generator electrical current steam and gas turbines, $\mathrm{MW}$;

$Q_{\mathrm{fwh}}, Q_{\mathrm{sc}}-$ thermal loading of feed water heater and steam consumers, MW;

$\Delta N_{\text {eml }}$ - electro mechanical energy losses on the shafts of the gas turbine and steam turbine power generator, $\mathrm{MW}$;

$\Delta Q_{c}-$ loss of heat in the condenser of the steam turbine, MW;

$N_{i k}-$ the power consumed by the compressor of GTPP, MW

Gross efficiency of CCGT defined by the formula [4]:

$$
\eta_{C C G T}^{g}=\frac{N^{\mathrm{gt}}+N^{\mathrm{st}}+Q_{\text {fwh }}}{{ }_{\text {CCGT }} Q_{l}^{o}}
$$

Where: ${ }_{\mathrm{CCGT}}$-fuel consumption in CCGT, $\mathrm{kg} / \mathrm{s}$; 


$$
B_{C C G T}=B_{g p}+B_{s p}=\frac{Q_{s g}}{Q_{l}^{o} \cdot \eta_{s g}}+\frac{Q_{c c}}{Q_{l}^{o} \cdot \eta_{c c}}
$$

Where: $B_{g p}, B_{s p}$ - consumption of fuel in the steam and gas parts of combined-cycle plant, $\mathrm{kg} / \mathrm{s}$;

$Q_{c c}$ - amount of thermal energy produced in the combustion chamber, MW.

$Q_{l}^{o}$-lower operating heat of combustion, $\mathrm{kj} / \mathrm{kg}$

$\eta_{s g}$-efficiency of low-pressure steam generator 0.933

$\eta_{c c}$-efficiency of combustion chamber, 0.99 [3].

Calculation of the relative electricity consumption for auxiliary needs of turbine

$$
K_{a n}=\frac{N_{f d}+\mathrm{N}_{f h}+\mathrm{N}_{p}+\mathrm{N}_{f p}}{\mathrm{~N}_{e}} 100 \%
$$

$\mathrm{N}_{f d}$-electricity consumption for the forced-draft device, $\mathrm{kW}$

$\mathrm{N}_{f h}$ - consumption of electricity feed water heater, $\mathrm{kW}$

$\mathrm{N}_{p}$ - electricity consumption for circulation, condensate and drainage pumps, $\mathrm{kW}$

$\mathrm{N}_{f p}$ - electricity consumption for feed pumps, $\mathrm{kW}$

Additional production of thermal energy and the power consumption in the compressor is calculated as follows [6]:

$$
Q h p=\Delta Q c+N h p, M W
$$

Where: Nhp - compression work, MW

$$
\begin{array}{r}
N h p=\frac{Q h p}{\phi}, M W \\
Q_{h p}=\frac{Q_{s \lg h}}{1-\frac{1}{\varphi}}, M W
\end{array}
$$

Where: $\varphi$ - coefficient of performance or COP of a heat pump;

$Q_{s \operatorname{lgh}}$-thermal energy from the source of low-grade heat

Gross efficiency of PGU-190/220 with the heat pump

The relative electricity consumption for auxiliary needs of turbine with heat pump

$$
\eta_{C C G T}^{g}=\frac{N^{\mathrm{gt}}, N^{\mathrm{st}}+Q_{\mathrm{fwh}}+Q_{\mathrm{hp}}}{\mathrm{B}_{\text {CCGT }} Q_{l}^{O}}
$$




$$
\mathrm{K}_{\mathrm{an}}^{\mathrm{hp}}=\frac{\mathrm{N}_{\mathrm{fd}}+\mathrm{N}_{\mathrm{fh}}+\mathrm{N}_{\mathrm{hp}}+\mathrm{N}_{\mathrm{fp}}}{\mathrm{N}_{\mathrm{e}}} 100 \%
$$

To determine the degree of the influence on temperature difference and the main indicator of the efficiency of heat pumps (the coefficient of performance), we calculated the characteristics of heat pump for the heat pump with a compressor on the same shaft as the PSU, intercooled and subcooler [7]. As a working agents, the R134a, R152a, R600 and R600a.were selected.

Initial data for the calculation of the heat pump is shown (Table 1)

Table 1. Initial data for the calculation of a heat pump.

\begin{tabular}{|c|c|c|}
\hline Parameter & Value & Units \\
\hline $\begin{array}{c}\text { Low-grade coolant temperature (refrigerant) at the inlet of the } \\
\text { heat pump tlg1 }\end{array}$ & 30 & ${ }^{\circ} \mathrm{C} ;$ \\
\hline $\begin{array}{c}\text { Low-grade temperature of the coolant (Freon) after the heat } \\
\text { pump tlg2 }\end{array}$ & 15 & ${ }^{\circ} \mathrm{C} ;$ \\
\hline $\begin{array}{c}\text { High-grade temperature of the coolant (hot water) at the inlet of } \\
\text { the heat pump thg1 }\end{array}$ & 20 & ${ }^{\circ} \mathrm{C} ;$ \\
\hline Hot water temperature after the heat pump thg2 & $30 \ldots 90$ & ${ }^{\circ} \mathrm{C} ;$ \\
\hline $\begin{array}{c}\text { Outdoor temperature to } \\
\text { Changes in temperature at the outlet of the heat exchangers: the } \\
\text { evaporator De, CONDENSER Dc, subcooler Ds }\end{array}$ & -10 & ${ }^{\circ} \mathrm{C} ;$ \\
\hline Superheat steam in the intermediate heat exchanger Dss & 20 & ${ }^{\circ} \mathrm{C}$ \\
\hline Electromechanical efficiency & 0.95 & ${ }^{\circ} \mathrm{C}$. \\
\hline Transmission efficiency & 0.95 & \\
\hline
\end{tabular}

For comparison, we also presented theoretically possible coefficient of performance, which is defined by the Equation:

$$
\varphi_{p}=\frac{t_{\mathrm{hg} 2}+273.15}{t_{\mathrm{hg} 2}-\mathrm{t}_{\mathrm{lg} 1}}
$$

The heat generation / electric output ratio can be considered as a reverse value of electric / heat output ratio (equivalent of the conversion ratio of heat pumps) $[8,9]$ :

$$
\varphi_{\text {hppchs }}=\frac{1}{E}=\frac{h_{\text {exir }}^{\prime \prime}-h_{\text {exir }}^{\prime}}{\eta_{o i} \eta_{m} \eta_{e}\left(h_{\text {exir }}-h_{\text {condenser }}\right)}
$$

Where: $h$ "exir, h'exir - enthalpy of steam input and enthalpy of water leaving network heater, $\mathrm{kj} / \mathrm{kg}{ }^{\circ} \mathrm{C}$;

$\eta_{o i}$ - relative internal turbine's efficiency;

$\eta_{m} \eta_{e}$-electromechanical turbine's efficiency;

$h "$ condenser - enthalpy of steam in the condenser.

Accordingly, the heat fuel consumption for electricity generation for heat pump 


$$
\Delta Q_{r}^{\mathrm{IES}}=\frac{\Delta N}{\eta_{r}^{\mathrm{IES}}}
$$

Where - $\eta_{r}^{\text {IES }}$ the efficiency of the replacement IES;

\section{Results}

According to the method we listed above we were in compliance with thermal balance and were able to calculate the efficiency of the existing CCGT -190/220.

Consumption of heat in the CCGT, perceived in the steam cycle:

$$
Q_{p c}=330.12+51.12=381.24 M W
$$

The consumption of heat spent to operate the gas parts of combined-cycle plant:

$$
Q_{g t}=145.325 \mathrm{MW}
$$

Losses of warmth with the leaving gases after the gas-water heater

$$
\Delta Q_{\mathrm{lg}}=197.2+77.184=120.016 \mathrm{MW}
$$

The heat of the fuel supplied to the working fluid in the cycle of CCGT:

$$
Q_{c}=381.24+144.5+120.016=645.756 M W
$$

However, the heat of the working fluid is distributed as follows.

$$
Q_{c}=63+133+163+0+52.515+120.016+35.4+75.785=642.716 \mathrm{MW}
$$

The deviation is less than $0.5 \%$

Fuel consumption in CCGT:

$$
{ }^{B} C C G T=B_{g p}+B_{s p}=\frac{330.12}{35.8 \cdot 0,933}+\frac{315.636}{35.8 \cdot 0.99}=9.88+8.91=18.79 \mathrm{~kg} / \mathrm{s}
$$

Gross efficiency of CCGT

$$
\eta_{C C G T}^{g}=\frac{63+133+163}{18.7935 .8}=0.504
$$

The relative electricity consumption for auxiliary needs of turbine

$$
K_{a n}=\frac{1829.55+1189.4+1072.1+3447.3}{133000+63000}=3.85 \%
$$

Thus, the net efficiency of the PGU-190/220:

$$
\eta=0.504(1-0.0385)=0.485
$$

Consider the change in the heat balance and indices of PSU calculated above by using heat pumps. 
The source of low-grade heat is a water cooling system. However, we reject the tower in this case, because capacitor plays a role of the evaporator of heat pump.

The main impact on efficiency of the thermal pump is exerted by a difference in temperatures of evaporation and condensation of Freon. Therefore, it depends on temperature of the low-potential heat carrier after the thermal pump and temperature of the high-potential heat carrier (hot water) at the exit from the thermal pump.

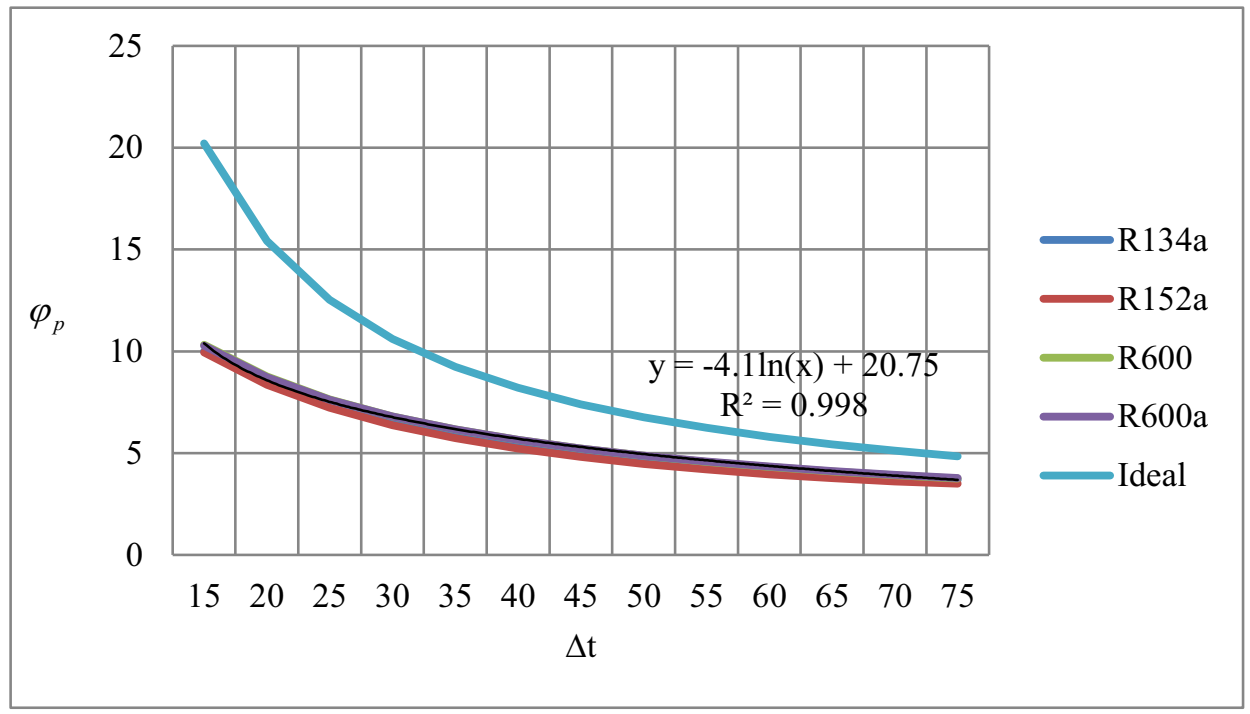

Fig.3. Dependence the COP of a heat pump from the temperature difference between the evaporator and the condenser.

The results indicate that the COP of a heat pump mainly depends on the temperature difference between the receiver and the source of heat, and the type of working fluid to a small degree.

The dependence of COP of a heat pump's temperature difference between the evaporator and condenser for Freon can be expressed by the formula:

$$
\mu_{h p}=-4.1 \ln \Delta t+20.75
$$

The results of calculation of CCGT efficiency with heat pump for heating water for domestic hot water (DHW), and before the chemical water treatment are presented in Table 2.

Table 2. Options for the use of heat pumps to the power station.

\begin{tabular}{|c|c|c|}
\hline Options & Chemical water treatment & DHW \\
\hline $\begin{array}{c}\text { The temperature difference in the } \\
\text { evaporator and condenser }\end{array}$ & 25 & 70 \\
\hline The coefficient of performance & 7.55 & 3.31 \\
\hline Heat generation, MW & 40.8 & 50.59 \\
\hline $\begin{array}{c}\text { The electricity consumption for } \\
\text { compressor drive, MW }\end{array}$ & 5.4 & 15.19 \\
\hline $\begin{array}{c}\text { The percentage of electricity } \\
\text { consumption for own needs, \% }\end{array}$ & 4.84 & 9.83 \\
\hline Netefficiency,\% & 56.56 & 54.9 \\
\hline
\end{tabular}


Using the heat pump is most effective when small temperature difference occurs between the condenser and evaporator.

We estimated a ratio of under produced electrical energy and generated thermal energy of unit CCGT-190/220.

When comparing the COP of a heat pump and the underproduction of generated thermal energy, we can conclude that the use of the heat pump is more efficient than the use of steam extraction and vice versa [10].

The steam consumption in CCGT-190/220 condenser is $56.19 \mathrm{~kg} / \mathrm{s}$, the absolute pressure in turbine condenser is $0.063 \mathrm{kgf} / \mathrm{cm} 2$, and the loss of heat in the steam turbine condenser is $35.4 \mathrm{MW}$. This thermal energy can be used for various purposes: to heat water before chemical water treatment, replace the regenerative heating, heating hot water for one's own needs, and to heat the coolant for third-party users [11-13]. For water purification it is necessary to heat the water from 10 to $300 \mathrm{C}$, and for DHW from 5 to $6500 \mathrm{C}$.

This method allows comparison of efficiency of the heat pump and steam extraction for heating water CHP.

Table 3. Options for the use of heat pumps to the power station.

\begin{tabular}{|c|c|c|}
\hline Options & Chemical water treatment & DHW \\
\hline $\begin{array}{c}\text { The temperature difference in the } \\
\text { evaporator and condenser }\end{array}$ & 25 & 70 \\
\hline The coefficient of performance & 7.55 & 3.31 \\
\hline $\begin{array}{c}\text { Enthalpy of steam input network heater, } \\
\mathrm{kj} / \mathrm{kg} \text {; }\end{array}$ & 2539 \\
\hline $\begin{array}{c}\text { Enthalpy of water leaving network heater, } \\
\mathrm{kj} / \mathrm{kg} \text {; }\end{array}$ & 267.9 \\
\hline $\begin{array}{c}\text { The enthalpy of steam in the condenser of } \\
\text { the steam turbine }\end{array}$ & 2282.7 \\
\hline $\begin{array}{c}\text { Internal relative, mechanical and electrical } \\
\text { efficiencies of the steam turbine }\end{array}$ & 0.833 \\
\hline $\begin{array}{c}\text { Underproduction of the electric power } \\
\text { of to generated thermal energy }\end{array}$ & \multirow{2}{|c|}{10.64} \\
\hline $\begin{array}{c}\text { Comparison of the COP of heat pump and } \\
\text { underproduction of to generated thermal } \\
\text { energy }\end{array}$ & 3.083 & 7.3 \\
\hline
\end{tabular}

Overall, Table 3 shows that for the chemical water treatment it is more efficient to use heat pumps.

\section{Discussion}

This method allows comparison of efficiency of the heat pump and steam extraction for heating water CHP, but it does not consider the possibility of thermal or electric energy from the replacement's source.

We consider two options for water heating for DHW $[8,9]$ :

1 - Electricity generation replacement IES spent on a heat pump (CCGT with a heat pump + IES);

2 -Generated heat development in the boiler room (CCGT with waste heat boiler).

Under generation electricity in the comparison version is the cost of electricity in the compressor of the heat pump - 15.19 MW. As a source of electrical energy used PGU-IES. Usually, such plants have about $50-52 \%$ efficiency.

In the case of CCGT with boiler, heat generation will be Qtnu - 51.49 MW. Then additional flow of heat in the boiler will be 


$$
\Delta Q_{r}^{\mathrm{IES}}=\frac{15.19}{0.5}=30.37 \mathrm{MW}
$$

The difference between the total cost of fuel options under consideration is $24.03 \mathrm{MW}$ and shows savings (deficit) of one embodiment of fuel in relation to another. The use of this criterion allows us to objectively identify strengths of matched types of thermal circuits cogeneration plant with heat pump, without the use of fuel dividing methods and type of energy produced.

Using heat pumps for chemical water treatment is most effective when considering the heat balance of PSU. But the use of heat pumps for heating the heat transfer medium to higher temperatures as effective when considering a substitute source of heat and electrical energy.

\section{Conclusions}

The heat-transfer agent heat pump, when heated uses low-grade heat TPP and increases heat output, but consumes the electricity. Using a heat pump is effective for a small temperature difference between the condenser and the evaporator. Good example is heating water before chemical treatment. This method is more efficient than using a replacement boiler and it is used in steam selection. Further study assumes economic кationale use this technology to calculate capital costs and payback periods.

\section{References}

1. http://minenergo.gov.ru/aboutminen/energostrategy

2. E. Olejnikova, PhD Thesis, 22 (2015)

3. N. Kirsanova, Materialy 54-j mezhdunarodnoj nauchnoj studencheskoj konferencii 1, 34 (2016)

4. S. Canaev, V. Burov, A. Remezov, Gazoturbinnyei parogazovye ustanovki teplovyh ehlektrostancij (Moscow, 2006)

5. A. Matveeva, Raschet pokazatelej ehkonomichnosti gazoturbinnyh I parogazovyh ustanovok (Tomsk, 2014)

6. A. Bogdanov, Primeneni eteplovyh nasosov v «bolshoy» energetike (Krasnoyarsk, 2009)

7. P. Tretyakova, Energosberezhenie na Kurganskoy TEC-2 za schet utilizacii nizkopotencialnoy teploty (Omskiy nauchnyy vestnik, Omsk, 2014)

8. A. Sokolov, PhD Thesis, 54 (2004)

9. A. Albul, PhD Thesis, 36 (2013)

10. P. Shchinnikov, Vestnik SGTU 1,139-149 (2004)

11. A. Andryushchenko, Kombinirovannye sistemy energosnabzheniya (Teploenergetika, Moscow, 1997)

12. O. Stepanov, P. Tretyakova, MATEC Web of Conferences 1, 73 (2016)

13. Feder. zakon 23.11.2009 № 261-FZ, Rossiyskayagazeta (2009)

14. A. Batukhtin, V. Makkaveev, Primenenie optimizacionnyh modeley funkcionirovaniya system teplosnabzheniya dlya snizheniya sebestoimosti teplovoynergii I uvelicheniya raspolagaemoy moschnostistancii (2010)

15. A. Batukhtin, A. Kalugin, Modelirovanie sovremennyh system centralizovannogo teplosnabzheniya (Moscow, 2011) 